Yournal of Agricultural Science
http://dergipark.gov.tr/yyutbd

Araştırma Makalesi (Research Article)

\title{
Changes in Qualitative and Quantitative Traits of Anatolian Chestnuts (Castanea sativa Mill.) Fruit Due to Balanced Macro Fertilization
}

\author{
Serdar TOPRAK ${ }^{1 *}$, Özgür ATEŞ², Gülser YALÇIN ${ }^{3}$, Kadriye TAŞPINAR $^{4}$ \\ ${ }^{1}$ Agricultural Production and Training Center, Department of Plant Production, Söke, Aydın, Turkey \\ ${ }^{2,3,4}$ Transitional Zone Agricultural Research Institute, Department of Soil and Water Research, Eskișehir, Turkey \\ 'https://orcid.org/0000-0003-3939-8530 2https://orcid.org/0000-0002-9345-417X ${ }^{3}$ https://orcid.org/0000-0002-8838-3055 \\ ${ }^{4}$ https://orcid.org/0000-0002-9781-7222 \\ Sorumlu yazar e-posta: serdar.toprak@gmail.com
}

Article Info

Received: 26.10 .2020

Accepted: 23.04.2021

Online Published 30.06.2021

DOI: $10.29133 /$ yyutbd. 816155

\section{Keywords}

Chestnut,

Fertilization,

Fruit,

Nutrition,

Yield,

Quality.

\begin{abstract}
The aim of this study was to determined effect of different doses of $\mathrm{N}$ : P: K applications on fruit yield and some quality traits in Anatolian chestnut in Bursa (Turkey) ecological condition during 2013 and 2014. In the research, triple experimental zones were determined in a 20-year-old chestnut orchard. Each of these experimental zones consisted of 30 trees. As experimental treatments, 1.1, 2.2, 3.3, and $4.4 \mathrm{lb} \mathrm{N}$ tree $^{-1}$ (N application zone; NAZ), 0.55, 1.1, 1.65, and $2.2 \mathrm{lb}$ $\mathrm{P}$ tree $^{-1}$ (P application zone; PAZ), 1.1, 2.2, 3.3, and $4.4 \mathrm{lb} \mathrm{K}$ tree $\mathrm{e}^{-1}$ (K application zone; KAZ) were applied except for the control dose. The fertilizer doses were applied by mixing to $30 \mathrm{~cm}$ depth of tree canopy soil in April. According to analyses of collected, nitrogen, phosphorus, and potassium affected fruit yield by 30,31 , and $27 \%$, respectively. Total protein increased the fastest at the nitrogen application's zone (NAZ) at an average of $14 \%$ rate. The highest increasing in carbohydrate, starch, and invert sugar was recorded as 20,24 , and $18 \%$, respectively at N: P: K application's zone.
\end{abstract}

\section{Dengeli Makro Gübrelemeye Bağlı Olarak Anadolu Kestanesi (Castanea sativa Mill.) Meyvelerinin Kalitatif ve Kantitatif Özelliklerinde Değişimler}

\section{Makale Bilgileri}

Geliș: 26.10 .2020

Kabul: 23.04 .2021

Online Yayınlanma 30.06.2021

DOI: $10.29133 /$ yyutbd.816155

\section{Anahtar kelimeler}

Kestane,

Gübreleme,

Meyve,

Beslenme,

Verim,

Kalite.
Öz: Bu çalışmanın amacı, Bursa (Türkiye) ekolojik koşullarında 2013 ve 2014 yıllarında Anadolu kestanesinde farklı dozlarda N: P: K uygulamalarının meyve verimi ve bazı kalite özellikleri üzerindeki etkisinin belirlenmesidir. Araştırmada, 20 yıllık bir kestane bahçesinde örneklenen üçlü deneme bölgelerinde gerçekleştirilmiştir. Bu deneme bölgelerinin her biri 30 ağaçtan oluşmaktadır. Deneme konuları olarak, kontrol dozu haricinde 1.1, 2.2, 3.3 ve $4.4 \mathrm{lb} \mathrm{N}$ ağaç-1 ( $\mathrm{N}$ uygulama bölgesi; NAZ), 0.55, 1.1, 1.65 ve $2.2 \mathrm{lb} \mathrm{P}$ ağaç-1 (P uygulama bölgesi; PAZ), 1.1, 2.2, 3,3 ve 4,4 lb K ağaç-1 (K uygulama bölgesi; KAZ) uygulanmıştır. Gübre dozları Nisan ayında $30 \mathrm{~cm}$ derinliğindeki ağaç taç izdüşümü toprağına karıştırılarak uygulanmıştır. Elde edilen verilere göre azot, fosfor ve potasyum meyve verimini sirasiyla \% 30, \% 31 ve \% 27 oranında etkilemiştir. Toplam protein, en hılı nitrojen uygulama bölgesinde (NAZ) ortalama \% 14 oranında artmıştır. Karbonhidrat, nişasta ve invert şekerde en yüksek artış N, P, K uygulama bölgelerinde sırasıyla \% 20, 24 ve 18 olarak kaydedilmiştir. 


\section{Introduction}

Generally, macro fertilization defines the three essential nutrients nitrogen, phosphorus, and potassium needed by cultivated plants. It has direct effects on the vegetative and generative development of plants as well as fruit yield and quality. Chestnuts are wealthy in starch and sugars, principally monosaccharides, and disaccharides such as glucose, fructose, sucrose, and raffinose. Besides, chestnuts diverge from other nuts for their low-fat content which makes them an ideal fit for high complicated carbohydrates and they have an inimitable taste (Vasconcelos et al., 2010). Chestnut fruits are highly esteemed and widely consumed throughout Europe, America, and Asia. Worldwide chestnut production is 2327500 tons. Chestnuts are mainly cultivated in China (1 879000 tons), Bolivia (84 800 t.), Turkey (64 750 t.), and the Republic of Korea (56 200 tons) (FAO, 2019).

A fertilizer program is needed to make fertilizer product profitability and get products of high quality in chestnut production. If chemical fertilization is to be applied, fertilizers of the appropriate type and quantity can be determined by a regular soil analysis. Regardless of the type of fertilizer, applications have to be passed in spring and never fertilization after June (Wahl, 2002). Because of the gathering of potential in fruit, nitrogen fertilizers could be expected to affect plenty of quality properties, primarily protein content in chestnut. It has been reported that low levels of nitrogen in chestnuts while cause poor growth and reduced flowering, low phosphorus levels cause a decrease in the number of developing female flowers (Rutter et al., 1990).

The goal of this study is to determine the effect of $\mathrm{N}$ : P: K mineral fertilizer applications on fruit qualitative and quantitative properties in mature Anatolian chestnut trees. Also, this study is to prove the change of some nutritional values of sugar chestnuts with macro fertilization.

\section{Materials and Methods}

\subsection{Site properties}

The experiment was carried out in a chestnut orchards of Bursa in the Osmanoğlu cultivar the sweet Anatolian chestnut trees of 20 years old during 2013 and 2014. Chestnut orchard was divided into three fertilization zones as nitrogen application zone (NAZ), phosphorus application zone (PAZ), and potassium application zone (KAZ). The study was prepensed as a randomized parcel design with three replications and two trees in each parcel. Fertilization was applied to a total of 90 trees.

Nitrogen fertilizer applications were adjusted to be $\mathrm{N}_{0}: 0, \mathrm{~N}_{1}: 1.1, \mathrm{~N}_{2}: 2.2, \mathrm{~N}_{3}: 3.3, \mathrm{~N}_{4}: 4.4 \mathrm{lb}$ tree $^{-1}$, phosphorus fertilizer applications, $\mathrm{P}_{0}: 0, \mathrm{P}_{1}: 0.55, \mathrm{P}_{2}: 1.1, \mathrm{P}_{3}: 1.65, \mathrm{P}_{4}: 2.2 \mathrm{lb}$ tree ${ }^{-1}$ and potassium fertilizer applications, $\mathrm{K}_{0}: 0, \mathrm{~K}_{1}: 1.1, \mathrm{~K}_{2}: 2.2, \mathrm{~K}_{3}: 3.3, \mathrm{~K}_{4}: 4.4 \mathrm{lb}$ tree $^{-1}$. Moreover, support fertilizers were applied for nitrogen application treatments as $1.65 \mathrm{lb} \mathrm{P}_{\text {tree }}^{-1}$ and $3.3 \mathrm{lb} \mathrm{K}$ tree ${ }^{-1}$, for phosphorus application treatments as $3.3 \mathrm{lb} \mathrm{N}$ tree $^{-1}$ and $3.3 \mathrm{lb} \mathrm{K}_{\text {tree }}{ }^{-1}$, for potassium application treatments as 3.3 $\mathrm{lb} \mathrm{N}$ tree $^{-1}$ and $1.65 \mathrm{lb} \mathrm{P}$ tree ${ }^{-1}$. Treatments and support fertilizers were applied to the canopy of the chestnut tree in April month mixed in 0-30 cm soil depth. In the research, urea $\left(\mathrm{CH}_{4} \mathrm{~N}_{2} \mathrm{O}\right)$ was used as a nitrogen origin, triple superphosphate $\left(\mathrm{Ca}\left(\mathrm{H}_{2} \mathrm{PO}_{4}\right)_{2} \cdot \mathrm{H}_{2} \mathrm{O}\right)$ as a phosphorus origin, and potassium chloride $(\mathrm{KCl})$ as a potassium origin.

The territory is located in the Marmara and the Aegean climate transitional zone. In the vegetation period (from March to October), the total amount of annual rainfall was $364.4 \mathrm{~mm}$ in the first year and $398.9 \mathrm{~mm}$ in the second year. The average temperature throughout the study was consistent with the long-term average temperature $(18.3 \mathrm{C})$. Also, the total rainfall was coherent with the total rainfall long term years. Climate data for the experimental orchard and periods were shown in Figure 1. 


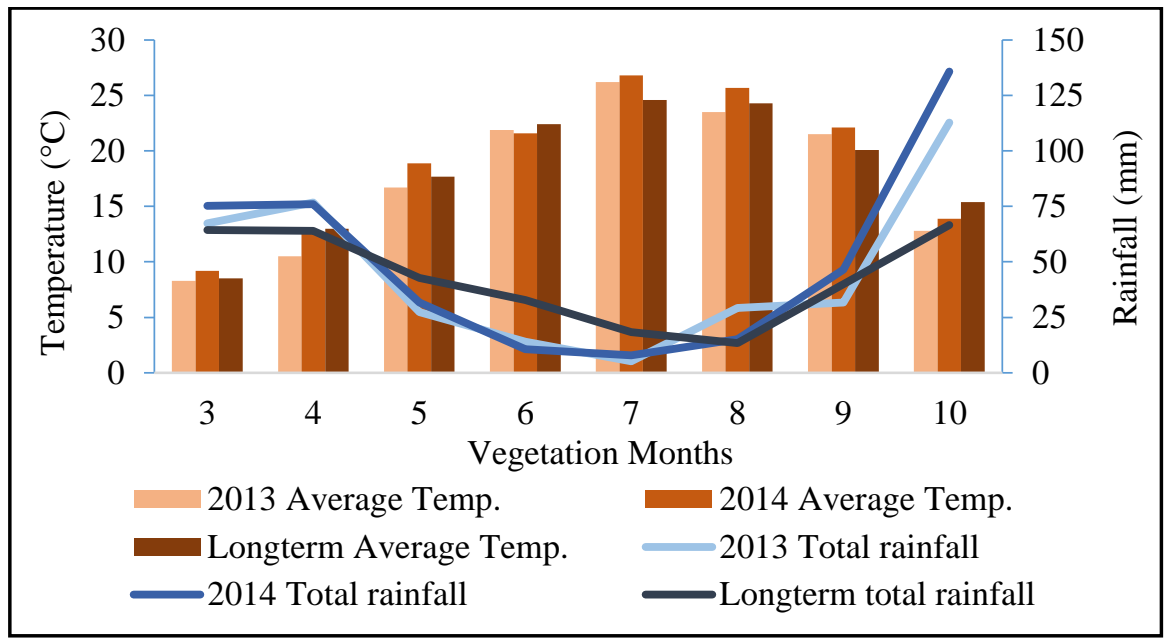

Figure 1. Climate data of the research site during the chestnut vegetation period over two years.

The soil samples of the research site were taken in March. Some physical and chemical analyses of soils concerning to the chestnut orchard were presented in Table 2. According to results, when the soil properties of the chestnut orchard were examined, it was determined that the soil's physical structure was loamy, the soil $\mathrm{pH}$ was slightly acidic (5.65), and organic matter $(1.51 \%)$ were insufficient. It was found that the total salt $(0.04 \%)$ and $\mathrm{CaCO} 3(0.38 \%)$ content of the soil were low levels. Also, the macronutrient contents were determined to be insufficient and micronutrient contents were found to be sufficient in the soil.

Table 1. Some soil physicochemical characteristics of the research orchard $(0-30 \mathrm{~cm} \mathrm{depth})$

\begin{tabular}{|c|c|c|c|c|c|}
\hline Soil characteristics & & Methods & Soil characteristics & & Methods* \\
\hline Soil texture & Loamy & Bouycous & Potassium $\left(\mathrm{mg} \mathrm{kg}^{-1}\right)$ & 124.2 & $\mathrm{NH}_{4} \mathrm{OAc}$ \\
\hline Total Salt (\%) & 0.04 & Saturation sludge & Calcium $\left(\mathrm{mg} \mathrm{kg}^{-1}\right)$ & 620.8 & $\mathrm{NH}_{4} \mathrm{OAc}$ \\
\hline $\mathrm{pH} ; 1: 1(\mathrm{w} / \mathrm{v})$ & 5.65 & Saturation sludge & Magnesium $\left(\mathrm{mg} \mathrm{kg}^{-1}\right)$ & 152.3 & $\mathrm{NH}_{4} \mathrm{OAc}$ \\
\hline $\mathrm{CaCO}_{3}(\%)$ & 0.38 & Scheibler & Iron $\left(\mathrm{mg} \mathrm{kg}^{-1}\right)$ & 42.15 & DTPA \\
\hline Organic matter (\%) & 1.51 & Walkley-Black & $\operatorname{Zinc}\left(\mathrm{mg} \mathrm{kg}^{-1}\right)$ & 1.26 & DTPA \\
\hline Total nitrogen $(\%)$ & 0.05 & Kjendahl & Manganese $\left(\mathrm{mg} \mathrm{kg}^{-1}\right)$ & 51.24 & DTPA \\
\hline Phosphorus $\left(\mathrm{mg} \mathrm{kg}^{-1}\right)$ & 7.36 & Olsen & Cupper $\left(\mathrm{mg} \mathrm{kg}^{-1}\right)$ & 0.76 & DTPA \\
\hline
\end{tabular}

* $\mathrm{NH}_{4} \mathrm{OAc}$ : Amonium Acetate, DTPA: Diethylenetriaminepentaacetic acid.

\subsection{Harvest and biochemical analysis in fruit}

Chestnuts were harvested during the mercantile harvest period (mid-October) in Bursa when fruits reached a physiological maturity stage where the chestnut burs began to separate and the fruits had grown and brown color. To determine the gross yield of each tree, nuts were harvested by vibrating trees and picking by hand. The fruit samples of randomly sampled 120-150 gr nuts were analyzed by crushing them with mortar after removing their outer shell and seed shell (testa). Dry matter contents of the samples were determined by drying them in a hot air oven at $105^{\circ} \mathrm{C}$ overnight (12 h) (Ertürk et al., 2006).

The total protein content was calculated by multiplying the nitrogen content by the Kjeldahl method with a coefficient of 5.30 (AOAC, 1990). The dinitrophenol method was used in the analysis of total carbohydrate, total and invert sugar (Ross, 1959) using a Beckman Du 530 model spectrophotometer. The amount of starch was calculated by multiplying the value obtained by subtracting total sugars from total carbohydrates by a factor of 0.94 .

\subsection{Statistical analysis}

The data was analyzed by JMP according to the randomized parcels design. The differences between the average values and application years were determined by the LSD test and the 
relationships between the features examined were also estimated in the same statistic package. The means were grouped by the Duncan test.

\section{Results and Discussion}

\subsection{Fruit yield}

Fertilizers applied in a certain balance contributed significantly to chestnut yields at statistical levels $(\mathrm{p}<0.05)$ in all fertilizer application zones (Table 2). The fastest yield increasing was achieved in the nitrogen application zone (NAZ). In the first year, the yields increased by about $25 \%$ compared to the control, while the yields increased by about $37 \%$ in the second year. Statistical significance was showed at both the year and the dose level. Besides, year $\mathrm{x}$ fertilizer dose interaction was found to be statistically significant. The $\mathrm{N}_{3} \mathrm{PK}$ dose of average fruit yields came to the fore and the highest yield was recorded at this dose of balanced fertilizer. As it is known, when nitrogen is applied to plants, it causes an increase in nutrients in leaf tissues and thus an increase in yield (Centeno and Campo, 2011; Yağmur et al., 2019).

Table 2. Chestnut yields (lb tree $\left.{ }^{-1}\right)$ after balanced N:P:K applications.

\begin{tabular}{|c|c|c|c|c|c|c|}
\hline \multirow[b]{2}{*}{ Years } & \multicolumn{6}{|c|}{ Nitrogen Application Zone (NAZ) } \\
\hline & $\mathrm{N}_{0} \mathrm{PK}$ & $\mathrm{N}_{1} \mathrm{PK}$ & $\mathrm{N}_{2} \mathrm{PK}$ & $\mathrm{N}_{3} \mathrm{PK}$ & $\mathrm{N}_{4} \mathrm{PK}$ & Average \\
\hline 2013 & $60.5^{\text {def* }}$ & $58.7^{\mathrm{f}}$ & $63.6^{\mathrm{cd}}$ & $75.5^{\mathrm{a}}$ & $63.8^{\mathrm{cd}}$ & $64.4^{\mathrm{A}^{*}}$ \\
\hline 2014 & $51.5^{\mathrm{g}}$ & $59.2^{\text {ef }}$ & $66.2^{\mathrm{c}}$ & $70.4^{b}$ & $62.7^{\text {cde }}$ & $62.0^{\mathrm{B}}$ \\
\hline \multirow[t]{2}{*}{ Average } & $56.0^{\mathrm{D}^{*}}$ & $59.0^{\mathrm{C}}$ & $64.9^{\mathrm{B}}$ & $73.0^{\mathrm{A}}$ & $63.3^{\mathrm{B}}$ & \\
\hline & \multicolumn{6}{|c|}{ Phosphorus Applications Zone (PAZ) } \\
\hline Years & $\mathrm{P}_{0} \mathrm{NK}$ & $\mathrm{P}_{1} \mathrm{NK}$ & $\mathrm{P}_{2} \mathrm{NK}$ & $\mathrm{P}_{3} \mathrm{NK}$ & $\mathrm{P}_{4} \mathrm{NK}$ & Average \\
\hline 2013 & 48.6 & 54.1 & 59.0 & 60.3 & 49.5 & $54.3^{\mathrm{B}^{*}}$ \\
\hline 2014 & 47.1 & 54.8 & 61.6 & 64.9 & 55.9 & $56.8^{\mathrm{A}}$ \\
\hline \multirow[t]{2}{*}{ Average } & $47.9^{C^{*}}$ & $54.5^{\mathrm{B}}$ & $60.3^{\mathrm{A}}$ & $62.6^{\mathrm{A}}$ & $52.7^{\mathrm{B}}$ & \\
\hline & \multicolumn{6}{|c|}{ Potassium Applications Zone (KAZ) } \\
\hline Years & $\mathrm{K}_{0} \mathrm{NP}$ & $\mathrm{K}_{1} \mathrm{NP}$ & $\mathrm{K}_{2} \mathrm{NP}$ & $\mathrm{K}_{3} \mathrm{NP}$ & $\mathrm{K}_{4} \mathrm{NP}$ & Average \\
\hline 2013 & 47.4 & 47.4 & 56.0 & 60.6 & 58.1 & 53.9 \\
\hline 2014 & 49.4 & 53.9 & 55.2 & 62.5 & 62.8 & 56.8 \\
\hline Average & $48.4^{\mathrm{D}}$ & $50.7^{\mathrm{CD}}$ & $55.6^{\mathrm{BC}}$ & $61.5^{\mathrm{A}}$ & $60.5^{\mathrm{AB}}$ & \\
\hline
\end{tabular}

The capital letters represent the results of the Duncan test $(*, P<0.05)$ for averages, and lower case letters show the results of the Duncan test $(* \mathrm{P}<0.05)$ for interaction between years and treatments. There is no statistical difference between values not shown with letters.

In the balanced fertilization in the phosphorus application zone (PAZ), the highest yield was found at the $\mathrm{P}_{3} \mathrm{NK}$ dose. Statistically significant differences were obtained in both the years and the fertilizer dose level. But, Year x Fertilizer interaction was not significant. Fruit yields increased by an average of $35 \%$ in this zone. The most obvious reason for this situation is the nitrogen and potassium applications applied together. In the first year, the fruit yield increased by $24 \%$ compared to the control level, while in the second year it increased by approximately 33\%. Studies on cultivated plants have shown that phosphorus fertilizers significantly increase the amount of crops and continuous phosphorus application has stimulating effects on yield (Güneş et al., 2010).

Fruit yield increased by an average of $27 \%$ with a balanced fertilization in the potassium application zone (KAZ). Although there was no statistically significant difference between the application years, significant differences were obtained between the fertilizer doses. Besides, year $\mathrm{x}$ fertilizer interaction was not significant. In the first year, while fertilizer balanced potassium fertilizer applications increased the yield of approximately $28 \%$, in the second year, $27 \%$ yield increase was recorded. The highest fruit yield was detected in $\mathrm{K}_{3} \mathrm{NP}$ balanced fertilizer application. Potassium applications increase the size, yield, and quality of the fruit (Kacar and Katkat, 2011).

\subsection{Total protein}

According to the protein analysis results, no statistically significant $(\mathrm{p}<0.05)$ difference was found between the application years in all application zones. Despite, important differences have been obtained between the application levels. Also, year $\mathrm{x}$ fertilizer interaction was found to be statistically 
insignificant in all fertilizer application zones (Table 3). The fastest fruit protein content increase was

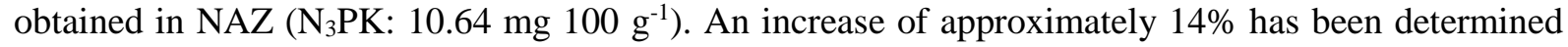
in this application compared to the control dose. The amount of nitrogen in the soil and many cultural practices could be effective on the protein ratio and quality (Fageria et al., 2011).

Table 3. Chestnut total protein $\left(\mathrm{g} 100 \mathrm{~g}^{-1}\right)$ contents after balanced $\mathrm{N}: \mathrm{P}: \mathrm{K}$ applications

\begin{tabular}{|c|c|c|c|c|c|c|}
\hline \multirow[b]{2}{*}{ Years } & \multicolumn{6}{|c|}{ Nitrogen Application Zone (NAZ) } \\
\hline & $\mathrm{N}_{0} \mathrm{PK}$ & $\mathrm{N}_{1} \mathrm{PK}$ & $\mathrm{N}_{2} \mathrm{PK}$ & $\mathrm{N}_{3} \mathrm{PK}$ & $\mathrm{N}_{4} \mathrm{PK}$ & Average \\
\hline 2013 & 9.20 & 9.56 & 10.51 & 10.61 & 10.13 & 10.00 \\
\hline 2014 & 9.42 & 9.61 & 10.54 & 10.66 & 9.86 & 10.02 \\
\hline \multirow[t]{2}{*}{ Average } & $9.31^{C^{*}}$ & $9.59^{\mathrm{C}}$ & $10.52^{\mathrm{A}}$ & $10.64^{\mathrm{A}}$ & $10.00^{\mathrm{B}}$ & \\
\hline & \multicolumn{6}{|c|}{ Phosphorus Applications Zone (PAZ) } \\
\hline Years & $\mathrm{P}_{0} \mathrm{NK}$ & $\mathrm{P}_{1} \mathrm{NK}$ & $\mathrm{P}_{2} \mathrm{NK}$ & $\mathrm{P}_{3} \mathrm{NK}$ & $\mathrm{P}_{4} \mathrm{NK}$ & Average \\
\hline 2013 & 6.05 & 6.61 & 6.03 & 6.04 & 6.11 & 6.17 \\
\hline 2014 & 6.19 & 6.43 & 6.76 & 6.34 & 5.81 & 6.31 \\
\hline \multirow[t]{2}{*}{ Average } & $6.12^{\mathrm{BC} *}$ & $6.52^{\mathrm{A}}$ & $6.40^{\mathrm{AB}}$ & $6.19 \mathrm{ABC}$ & $5.96^{\mathrm{C}}$ & \\
\hline & \multicolumn{6}{|c|}{ Potassium Applications Zone (KAZ) } \\
\hline Years & $\mathrm{K}_{0} \mathrm{NP}$ & $\mathrm{K}_{1} \mathrm{NP}$ & $\mathrm{K}_{2} \mathrm{NP}$ & $\mathrm{K}_{3} \mathrm{NP}$ & $\mathrm{K}_{4} \mathrm{NP}$ & Average \\
\hline 2013 & 6.68 & 6.87 & 6.98 & 7.25 & 7.24 & 7.01 \\
\hline 2014 & 6.85 & 6.98 & 7.03 & 7.33 & 7.27 & 7.09 \\
\hline Average & $6.77^{\mathrm{C}^{*}}$ & $6.92^{\mathrm{BC}}$ & $7.01 \mathrm{ABC}$ & $7.29^{\mathrm{A}}$ & $7.26^{\mathrm{AB}}$ & \\
\hline
\end{tabular}

The capital letters represent the results of the Duncan test $\left.{ }^{*}, \mathrm{P}<0.05\right)$ for averages, and lower case letters show the results of the Duncan test $(* \mathrm{P}<0.05)$ for interaction between years and treatments. There is no statistical difference between values not shown with letters.

However, the highest fruit protein content in PAZ was recorded as $6.52 \mathrm{mg} 100 \mathrm{~g}^{-1}$ for $\mathrm{P}_{1} \mathrm{NK}$ dose. An increase of $6.5 \%$ was achieved compared to the control level with this application. In addition, the lowest fruit protein content at the highest $\mathrm{P}$ level was determined as $5.96 \mathrm{mg} 100 \mathrm{~g}^{-1}$. So, when $\mathrm{N}$ and $\mathrm{K}$ were in equilibrium, increasing of $\mathrm{P}$ were decreased the protein content of fruit. This perhaps due to the negative interaction of nitrogenous and potassium fertilizers given in basic fertilization with the final phosphorus dose. As known, fertilization with high amounts of phosphorus causes the plants are not to benefit from sufficient nitrogen and potassium (Kacar and Katkat, 2011).

Potassium plays a role in protein synthesis in plant growth and is essential for the production of high-energy molecules such as ATP (Imas, 1999). The highest fruit protein content in KAZ was recorded as $7.29 \mathrm{mg} 100 \mathrm{~g}^{-1}$ for $\mathrm{K}_{3} \mathrm{NP}$. Unlike $\mathrm{P}$, fruit protein content increased as K levels increased. A $7.7 \%$ increase was detected at this dose compared to the control dose. The protein contents was reported between 3.43 and $13.28 \mathrm{~g} 100 \mathrm{~g}-1$ by researchers on chestnut. (Ertürk et al., 2006).

\subsection{Carbohydrate}

Statistically significant differences were obtained in fruit carbohydrate contents only in NAZ and KAZ both between years and between doses. In PAZ, on the other hand, no statistically significant difference was detected only between application doses. In addition, year $\mathrm{x}$ fertilizer interactions were found important in all regions. The second dose of fertilizers applied in NAZ and PAZ achieved the highest carbohydrate content. A decrease was noted with subsequent doses. However, in KAZ, the highest carbohydrate content was detected in the third application dose (Table 4). The highest

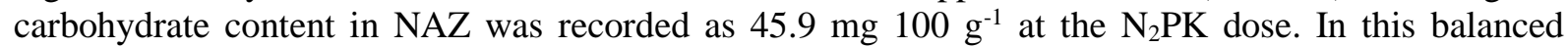
nitrogen application, an increase of $17.4 \%$ was achieved compared to the control dose. A decrease in the carbohydrate content of the fruit was noted at doses after this dose. As the amount of nitrogen applied to plants increases, the content of carbohydrates decreases (Rodrigues et al., 2006). 


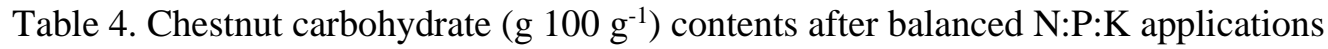

\begin{tabular}{|c|c|c|c|c|c|c|}
\hline \multirow[b]{2}{*}{ Years } & \multicolumn{6}{|c|}{ Nitrogen Application Zone (NAZ) } \\
\hline & $\mathrm{N}_{0} \mathrm{PK}$ & $\mathrm{N}_{1} \mathrm{PK}$ & $\mathrm{N}_{2} \mathrm{PK}$ & $\mathrm{N}_{3} \mathrm{PK}$ & $\mathrm{N}_{4} \mathrm{PK}$ & Average \\
\hline 2013 & $40.0^{\text {ef* }}$ & $40.3^{\mathrm{de}}$ & $41.9^{\mathrm{cd}}$ & $39.1^{\text {ef }}$ & $42.6^{c}$ & $40.8^{\mathrm{B}^{*}}$ \\
\hline 2014 & $38.2^{\mathrm{f}}$ & $46.1^{\mathrm{b}}$ & $49.9^{\mathrm{a}}$ & $44.5^{b}$ & $40.1^{\mathrm{e}}$ & $43.8^{\mathrm{A}}$ \\
\hline \multirow[t]{2}{*}{ Average } & $39.1^{D^{*}}$ & $43.2^{\mathrm{B}}$ & $45.9^{\mathrm{A}}$ & $41.8^{\mathrm{C}}$ & $41.3^{\mathrm{C}}$ & \\
\hline & \multicolumn{6}{|c|}{ Phosphorus Applications Zone (PAZ) } \\
\hline Years & $\mathrm{P}_{0} \mathrm{NK}$ & $\mathrm{P}_{1} \mathrm{NK}$ & $\mathrm{P}_{2} \mathrm{NK}$ & $\mathrm{P}_{3} \mathrm{NK}$ & $\mathrm{P}_{4} \mathrm{NK}$ & Average \\
\hline 2013 & $51.8^{\mathrm{cd}^{*}}$ & $52.9^{\mathrm{cd}}$ & $52.6^{\mathrm{cd}}$ & $51.1^{\mathrm{d}}$ & $51.4^{\mathrm{cd}}$ & $52.0^{\mathrm{B}^{*}}$ \\
\hline 2014 & $52.6^{\mathrm{cd}}$ & $53.6^{\mathrm{bc}}$ & $55.8^{\mathrm{a}}$ & $57.0^{\mathrm{a}}$ & $55.5^{\mathrm{ab}}$ & $54.9^{\mathrm{A}}$ \\
\hline \multirow[t]{2}{*}{ Average } & 52.2 & 53.3 & 54.2 & 54.1 & 53.5 & \\
\hline & \multicolumn{6}{|c|}{ Potassium Applications Zone (KAZ) } \\
\hline Years & $\mathrm{K}_{0} \mathrm{NP}$ & $\mathrm{K}_{1} \mathrm{NP}$ & $\mathrm{K}_{2} \mathrm{NP}$ & $\mathrm{K}_{3} \mathrm{NP}$ & $\mathrm{K}_{4} \mathrm{NP}$ & Average \\
\hline 2013 & $35.3^{\mathrm{e}^{*}}$ & $40.6^{c}$ & $40.5^{c}$ & $40.6^{c}$ & $39.8^{\mathrm{cd}}$ & $39.4^{B^{*}}$ \\
\hline 2014 & $38.1^{\mathrm{d}}$ & $42.7^{b}$ & $46.7^{\mathrm{a}}$ & $47.4^{\mathrm{a}}$ & $43.9^{\mathrm{b}}$ & $43.8^{\mathrm{A}}$ \\
\hline Average & $36.7^{C^{*}}$ & $41.7^{\mathrm{B}}$ & $43.6^{\mathrm{A}}$ & $44.0^{\mathrm{A}}$ & $41.9^{\mathrm{B}}$ & \\
\hline
\end{tabular}

The capital letters represent the results of the Duncan test $(*, \mathrm{P}<0.05)$ for averages, and lower case letters show the results of the Duncan test $\left({ }^{*} \mathrm{P}<0.05\right)$ for interaction between years and treatments. There is no statistical difference between values not shown with letters.

Besides, compared to the first application year, the carbohydrate increase was $7.3 \%$ in the

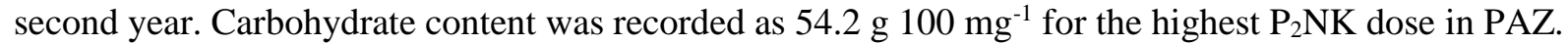
Compared to the control level, this dose increased by a 3.8\% rate. Furthermore, compared to the first year, the fruit carbohydrate content increased by $5.6 \%$ in the second year. Moreover, when there was enough phosphorus in the fruit, the amount of starch could be increase (Fageria et al., 2011). The fastest increase in carbohydrate content occurred a $19.9 \%$ increase in the $\mathrm{K}_{3} \mathrm{NP}$ dose was noted compared to the control dose in KAZ. Potassium was very effective on carbohydrate mechanism. In addition, continuously applied potassium increases the quality of cultivated plants (Kumar et al., 2006). In addition, the fastest carbohydrate increase among the years has been determined in KAZ. Carbohydrate content increase in the second year was recorded at approximately $11.1 \%$ compared to the first year.

\subsection{Total starch}

Starch content of chestnut fruit gave positive responses to balanced macro fertilization in all fertilizer application zones. The applied fertilizers were found to statistically significant contributions to the fruit starch content. However, significant statistical differences have been obtained in NAZ and KAZ both between years and between applications. Starch contents were found to be statistically significant in PAZ only between years. In addition, statistical differences in year $\mathrm{x}$ fertilizer interactions of all applications were recorded (Table 5).

The highest starch content in NAZ was determined as $35.7 \mathrm{mg} 100 \mathrm{~g}^{-1}$ at $\mathrm{N}_{2} \mathrm{PK}$ application. According to the control level, the starch content increased by about $20 \%$ in this application. Also, compared to the first year, the fruit starch content increased by $6 \%$ in the second year. In PAZ that another application zone, the highest starch content was recorded as $43.3 \mathrm{mg} 100 \mathrm{~g}^{-1}$ for $\mathrm{P}_{2} \mathrm{NK}$ application. Compared to the first year, the starch content in the fruit increased by $6.5 \%$ in the second year. However, after the second dose applied in both NAZ and PAZ, the starch content decreased despite the increased fertilizer applications. Also, when there was excessive phosphorus in fruit, the amount of starch perhaps decreased (Kumar et al., 2006). 


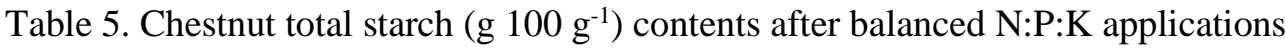

\begin{tabular}{|c|c|c|c|c|c|c|}
\hline \multirow[b]{2}{*}{ Years } & \multicolumn{6}{|c|}{ Nitrogen Application Zone (NAZ) } \\
\hline & $\mathrm{N}_{0} \mathrm{PK}$ & $\mathrm{N}_{1} \mathrm{PK}$ & $\mathrm{N}_{2} \mathrm{PK}$ & $\mathrm{N}_{3} \mathrm{PK}$ & $\mathrm{N}_{4} \mathrm{PK}$ & Average \\
\hline 2013 & $30.6^{\text {ef* }}$ & $31.1^{\text {de }}$ & $32.6^{\mathrm{cd}}$ & $29.1^{\mathrm{f}}$ & $33.2^{\mathrm{c}}$ & $31.3^{\mathrm{B}^{*}}$ \\
\hline 2014 & $29.0^{\mathrm{f}}$ & $35.5^{\mathrm{b}}$ & $38.9^{\text {a }}$ & $33.3^{c}$ & 29.4 ef & $33.2^{\mathrm{A}}$ \\
\hline \multirow[t]{2}{*}{ Average } & $29.8^{\mathrm{D}^{*}}$ & $33.3^{\mathrm{B}}$ & $35.7^{\mathrm{A}}$ & $31.2^{\mathrm{C}}$ & $31.3^{\mathrm{C}}$ & \\
\hline & \multicolumn{6}{|c|}{ Phosphorus Applications Zone (PAZ) } \\
\hline Years & $\mathrm{P}_{0} \mathrm{NK}$ & $\mathrm{P}_{1} \mathrm{NK}$ & $\mathrm{P}_{2} \mathrm{NK}$ & $\mathrm{P}_{3} \mathrm{NK}$ & $\mathrm{P}_{4} \mathrm{NK}$ & Average \\
\hline 2013 & $41.9^{\mathrm{de} e^{*}}$ & $42.2^{\mathrm{de}}$ & $41.8^{\mathrm{de}}$ & $40.4^{\mathrm{e}}$ & $40.7^{\mathrm{de}}$ & $41.4^{\mathrm{B}^{*}}$ \\
\hline 2014 & $42.5^{\text {cde }}$ & $42.8^{\mathrm{bcd}}$ & $44.8^{\mathrm{ab}}$ & $45.9^{\mathrm{a}}$ & $44.5 \mathrm{abc}$ & $44.1^{\mathrm{A}}$ \\
\hline \multirow{2}{*}{ Average } & 42.2 & 42.5 & 43.3 & 43.2 & 42.6 & \\
\hline & \multicolumn{6}{|c|}{ Potassium Applications Zone (KAZ) } \\
\hline Years & $\mathrm{K}_{0} \mathrm{NP}$ & $\mathrm{K}_{1} \mathrm{NP}$ & $\mathrm{K}_{2} \mathrm{NP}$ & $\mathrm{K}_{3} \mathrm{NP}$ & $\mathrm{K}_{4} \mathrm{NP}$ & Average \\
\hline 2013 & $24.8^{\mathrm{f*}}$ & $29.4^{\mathrm{cd}}$ & $28.9^{\mathrm{de}}$ & $29.0^{\mathrm{de}}$ & $28.1^{\mathrm{de}}$ & $28.0^{\mathrm{B}^{*}}$ \\
\hline 2014 & $27.2^{\mathrm{e}}$ & $31.1^{b c}$ & $34.8^{\mathrm{a}}$ & $35.3^{\mathrm{a}}$ & $32.1^{\mathrm{b}}$ & $32.1^{\mathrm{A}}$ \\
\hline Average & $26.0^{\mathrm{C}^{*}}$ & $30.3^{\mathrm{B}}$ & $31.8^{\mathrm{A}}$ & $32.2^{\mathrm{A}}$ & $30.1^{\mathrm{B}}$ & \\
\hline
\end{tabular}

The capital letters represent the results of the Duncan test $(*, P<0.05)$ for averages, and lower case letters show the results of the Duncan test $\left({ }^{*} \mathrm{P}<0.05\right)$ for interaction between years and treatments. There is no statistical difference between values not shown with letters.

Furthermore, the fastest increasing in fruit starch content was determined in KAZ. Approximately $24 \%$ increasing was determined for $\mathrm{K}_{3} \mathrm{NP}$ application compared to the control. In addition, a very fast increasing in sugar was found over the years. Fertilizers applied in the second year compared to the first application year increased the fruit sugar ratio by approximately $15 \%$. Potassium action in starch synthetase enzyme activity is quite high up to a certain grade (Fageria et al., 2011). Starch was transported to the storage organs especially in the entity of adequate potassium (Kacar and Katkat, 2011).

\subsection{Total sugar}

Significant statistical differences were recorded between total sugar content and all fertilizer applications in NAZ, PAZ, and KAZ. However, statistically, significant differences were detected between years and year $x$ fertilizer interactions only in NAZ (Table 6).

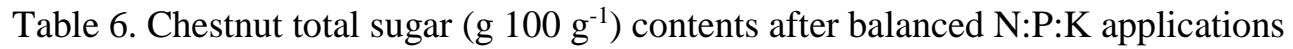

\begin{tabular}{|c|c|c|c|c|c|c|}
\hline \multirow[b]{2}{*}{ Years } & \multicolumn{6}{|c|}{ Nitrogen Application Zone (NAZ) } \\
\hline & $\mathrm{N}_{0} \mathrm{PK}$ & $\mathrm{N}_{1} \mathrm{PK}$ & $\mathrm{N}_{2} \mathrm{PK}$ & $\mathrm{N}_{3} \mathrm{PK}$ & $\mathrm{N}_{4} \mathrm{PK}$ & Average \\
\hline 2013 & $8.17^{\mathrm{c}^{*}}$ & $7.93^{\mathrm{c}}$ & $7.94^{\mathrm{c}}$ & $8.85^{b}$ & $7.97^{\mathrm{c}}$ & $8.17^{\mathrm{B}}$ \\
\hline 2014 & $8.00^{\mathrm{c}}$ & $9.08^{\mathrm{b}}$ & $9.41^{a b}$ & $9.79^{\mathrm{a}}$ & 9.44 ab & $9.14^{\mathrm{A}}$ \\
\hline \multirow[t]{2}{*}{ Average } & $8.09^{\mathrm{C} *}$ & $8.50^{\mathrm{BC}}$ & $8.67^{\mathrm{B}}$ & $9.32^{\mathrm{A}}$ & $8.71^{\mathrm{B}}$ & \\
\hline & \multicolumn{6}{|c|}{ Phosphorus Applications Zone (PAZ) } \\
\hline Years & $\mathrm{P}_{0} \mathrm{NK}$ & $\mathrm{P}_{1} \mathrm{NK}$ & $\mathrm{P}_{2} \mathrm{NK}$ & $\mathrm{P}_{3} \mathrm{NK}$ & $\mathrm{P}_{4} \mathrm{NK}$ & Average \\
\hline 2013 & 7.25 & 8.01 & 8.09 & 8.12 & 8.15 & 7.92 \\
\hline 2014 & 7.37 & 8.09 & 8.12 & 8.19 & 8.11 & 7.98 \\
\hline \multirow[t]{2}{*}{ Average } & $7.31^{\mathrm{B}^{*}}$ & $8.05^{\mathrm{A}}$ & $8.11^{\mathrm{A}}$ & $8.16^{\mathrm{A}}$ & $8.13^{\mathrm{A}}$ & \\
\hline & \multicolumn{6}{|c|}{ Potassium Applications Zone (KAZ) } \\
\hline Years & $\mathrm{K}_{0} \mathrm{NP}$ & $\mathrm{K}_{1} \mathrm{NP}$ & $\mathrm{K}_{2} \mathrm{NP}$ & $\mathrm{K}_{3} \mathrm{NP}$ & $\mathrm{K}_{4} \mathrm{NP}$ & Average \\
\hline 2013 & 8.98 & 9.27 & 9.75 & 9.78 & 9.94 & 9.54 \\
\hline 2014 & 9.14 & 9.64 & 9.70 & 9.87 & 9.73 & 9.62 \\
\hline Average & $9.06^{\mathrm{C}^{*}}$ & $9.46^{\mathrm{B}}$ & $9.73 \mathrm{AB}$ & $9.83 \mathrm{AB}$ & $9.84^{\mathrm{A}}$ & \\
\hline
\end{tabular}

The capital letters represent the results of the Duncan test $(*, \mathrm{P}<0.05)$ for averages, and lower case letters show the results of the Duncan test $(* \mathrm{P}<0.05)$ for interaction between years and treatments. There is no statistical difference between values not shown with letters.

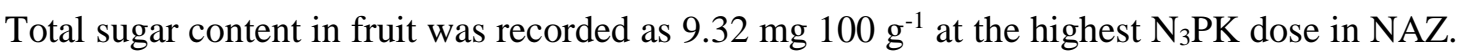
Against the control dose, a $15 \%$ increase in the fruit sugar content was determined at the $\mathrm{N}_{3} \mathrm{PK}$ dose. However, compared to the first year, the total sugar rate in the second year increased by approximately $12 \%$. But, the sugar content decreased at the final $\mathrm{N}$ dose. The sugar content decreases at increasing nitrogen doses (Kumar et al., 2006). The excess of nitrogen is elongated the vegetative progress term of the plant, delays blooming, and decreases sugar synthesis (Fageria et al., 2011). The total sugar 
content was found to be $8.16 \mathrm{mg} 100 \mathrm{~g}^{-1}$ at the $\mathrm{P}_{3} \mathrm{NK}$ dose and an increase of approximately $12 \%$ was determined compared to the control in PAZ. There was no statistical difference between years in the PAZ. However, the sugar content was noted as the highest in KAZ, with an average of $9.84 \mathrm{mg} 100 \mathrm{~g} \mathrm{~g}^{-1}$ in $\mathrm{K}_{4} \mathrm{NP}$. Despite the increasing potassium doses, there was an increase in the total sugar content of the fruit. An increase of about 9\% was obtained in the last dose compared to the control level. Plant nutrition with phosphorus and potassium contributes positively to sugar metabolism (Mengel, 1991).

\subsection{Invert sugar}

The invert sugar content in chestnuts was found to be very low compared to total sugar. The total sugar ratio of invert sugar was determined as 6.5, 6.2, and $12.6 \%$ in NAZ, PAZ, and KAZ, respectively. Year $\mathrm{x}$ fertilizer interaction was found to be statistically insignificant in all fertilizer application zones. Nevertheless, significant statistical differences were obtained both year and fertilizer doses in PAZ. However, $\mathrm{K}$ doses also made statistically significant contributions to the amount of invert sugar in the fruit (Table 7).

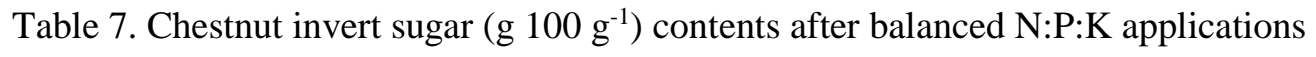

\begin{tabular}{|c|c|c|c|c|c|c|}
\hline \multirow[b]{2}{*}{ Years } & \multicolumn{6}{|c|}{ Nitrogen Application Zone (NAZ) } \\
\hline & $\mathrm{N}_{0} \mathrm{PK}$ & $\mathrm{N}_{1} \mathrm{PK}$ & $\mathrm{N}_{2} \mathrm{PK}$ & $\mathrm{N}_{3} \mathrm{PK}$ & $\mathrm{N}_{4} \mathrm{PK}$ & Average \\
\hline 2013 & 0.573 & 0.550 & 0.590 & 0.580 & 0.583 & 0.575 \\
\hline 2014 & 0.543 & 0.553 & 0.570 & 0.577 & 0.497 & 0.548 \\
\hline \multirow[t]{2}{*}{ Average } & 0.558 & 0.552 & 0.580 & 0.578 & 0.540 & \\
\hline & \multicolumn{6}{|c|}{ Phosphorus Applications Zone (PAZ) } \\
\hline Years & $\mathrm{P}_{0} \mathrm{NK}$ & $\mathrm{P}_{1} \mathrm{NK}$ & $\mathrm{P}_{2} \mathrm{NK}$ & $\mathrm{P}_{3} \mathrm{NK}$ & $\mathrm{P}_{4} \mathrm{NK}$ & Average \\
\hline 2013 & 0.477 & 0.514 & 0.507 & 0.443 & 0.450 & $0.478^{\mathrm{B} *}$ \\
\hline 2014 & 0.523 & 0.527 & 0.496 & 0.499 & 0.490 & $0.507^{\mathrm{A}}$ \\
\hline \multirow[t]{2}{*}{ Average } & $0.500 \mathrm{AB}^{*}$ & $0.520^{\mathrm{A}}$ & $0.501^{\mathrm{AB}}$ & $0.471^{\mathrm{B}}$ & $0.470^{\mathrm{B}}$ & \\
\hline & \multicolumn{6}{|c|}{ Potassium Applications Zone (KAZ) } \\
\hline Years & $\mathrm{K}_{0} \mathrm{NP}$ & $\mathrm{K}_{1} \mathrm{NP}$ & $\mathrm{K}_{2} \mathrm{NP}$ & $\mathrm{K}_{3} \mathrm{NP}$ & $\mathrm{K}_{4} \mathrm{NP}$ & Average \\
\hline 2013 & 0.537 & 0.611 & 0.690 & 0.640 & 0.610 & 0.618 \\
\hline 2014 & 0.560 & 0.607 & 0.610 & 0.557 & 0.610 & 0.589 \\
\hline Average & $0.548^{\mathrm{B}^{*}}$ & $0.609^{\mathrm{A}}$ & $0.650^{\mathrm{A}}$ & $0.599 \mathrm{AB}$ & $0.610^{\mathrm{A}}$ & \\
\hline
\end{tabular}

The capital letters represent the results of the Duncan test $(*, \mathrm{P}<0.05)$ for averages, and lower case letters show the results of the Duncan test $(* \mathrm{P}<0.05)$ for interaction between years and treatments. There is no statistical difference between values not shown with letters.

Increasing nitrogenous fertilizer applications showed a situation that did not affect invert sugar among all fertilizer applications. However, the highest fruit invert sugar content was detected at the $\mathrm{N}_{2} \mathrm{PK}$ application dose $\left(0.580 \mathrm{mg} 100 \mathrm{~g}^{-1}\right)$. Compared to the first year, the invert sugar content decreased by $5 \%$ in the second year. This situation paralleled the increase in nitrogen doses. But, the invert sugar content in the fruit decreased by $7.4 \%$ in the last two doses. The invert sugar content decreases in excess nitrogen doses (Fageria et al., 2011).

Phosphorus applications also affect showed similarly to NAZ. The highest invert sugar content for $\mathrm{P}_{1} \mathrm{NK}$ averaged $0.520 \mathrm{mg} 100 \mathrm{~g}^{-1}$, while it tended to decrease as increasing phosphorus doses. There was a $10.6 \%$ rate decline in the final $\mathrm{P}$ dose. Yet, against the first year, invert sugar increased by $6 \%$ in the second year in PAZ. The invert sugar content in the fruit gave positive responses to increasing $\mathrm{K}$ doses. The fastest increase occurred in this application zone. Compared to the control level, the $\mathrm{K}_{2} \mathrm{NP}$ dose increased the fruit invert sugar content by about $19 \%$. Whereas, there was a $5 \%$ decrease in the second year compared to the first year between the implementation years. In spite of potassium does not constitute a part of the structure of plant components, it increases the quality of fruits by providing the desired sugar-acid balance and maturing of the fruit (Kumar et al., 2006).

\subsection{Correlation analyses}

According to correlation analyses, a statistically significant strong positive relationship was found between chestnut fruit yield and all fertilizer application doses (Table 8). While there was a strong positive correlation between $\mathrm{N}$ and $\mathrm{K}$ applications on total protein content, $\mathrm{P}$ doses had no significant effect on fruit protein content. A statistically significant and strong correlation was noted 
between carbohydrate and starch contents and $\mathrm{P}$ and $\mathrm{K}$ applications. In addition, it has been determined that $\mathrm{N}$ has no effect on both carbohydrate and starch mechanisms. All applications made statistically significant and positive contributions to the total sugar ratio. A negative correlation was found between fruit invert sugar content $\mathrm{P}$ applications. However, statistically insignificant relationships were estimated between invert sugar in fruit and $\mathrm{N}$ and $\mathrm{K}$ applications.

Table 8. Relationship of chestnut yield and some quality properties due to balanced N: P: K applications according to Pearson's correlation model

\begin{tabular}{|c|c|c|c|}
\hline \multirow{2}{*}{$\begin{array}{l}\text { Qualitative and quantitative } \\
\text { parameters }\end{array}$} & \multicolumn{3}{|c|}{ Fertilizer Application Zones } \\
\hline & NAZ & PAZ & KAZ \\
\hline Yield $\left(\mathrm{kg} \mathrm{tree}^{-1}\right)$ & $0.620^{* * *}$ & $0.424^{*}$ & $0.752^{* * *}$ \\
\hline 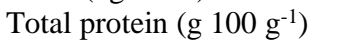 & $0.599^{* *}$ & $-0.239 \mathrm{~ns}$ & $0.617^{* *}$ \\
\hline 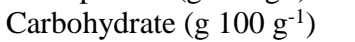 & $0.122^{\mathrm{ns}}$ & $0.415^{*}$ & $0.492^{* * *}$ \\
\hline Total starch $\left({\left.\mathrm{g} 100 \mathrm{~g}^{-1}\right)}^{-1}\right.$ & $0.041^{\mathrm{ns}}$ & $0.505^{*}$ & $0.439^{*}$ \\
\hline Total sugar $\left(\mathrm{g} 100 \mathrm{~g}^{-1}\right)$ & $0.385^{*}$ & $0.729^{* *}$ & $0.678^{* * *}$ \\
\hline 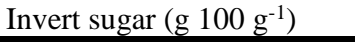 & $-0.026^{\mathrm{ns}}$ & $-0.424^{*}$ & $0.289^{\mathrm{ns}}$ \\
\hline
\end{tabular}

**. Correlation is significant at the 0.01 level, *. Correlation is significant at the 0.05 level, ns: not significant

\section{Conclusions}

The results of this study proved that balanced macro fertilization has an effect on the yield and some quality characteristics of chestnuts. However, chestnut tree is still accepted in the world as a forest tree. Therefore, the chestnut plant does not sufficiently care and cultural processes. Yet, as in other cultivated plants, chestnut needs some cultural processes such as soil cultivation, fertilization and irrigation. Although this study is a regional study, it seems effective in revealing the nutrients that affect the yield and quality of a mature chestnut tree and drawing a certain road map. Also, different regional macro plant nutrients applied in the same garden presented various evidence for the parallelism of the study.

In the light of all the data, the most appropriate $\mathrm{N}$ dose to be applied to the soil per tree in midApril was determined as $3.3 \mathrm{lb}, \mathrm{P}$ dose $1.65 \mathrm{lb}$ and $\mathrm{K}$ dose $3.3 \mathrm{lb}$. In addition to this situation, it is necessary to make organic fertilization in order to increase the organic matter in chestnut orchards. Thus, the effectiveness of other chemical fertilizers applied to the soil will increase and some physical and biological properties of the soil will be enriched in chestnut orchards.

\section{References}

AOAC, (1990). Association of Official Agricultural Chemists Official Methods of Analysis. 15th ed. Washington, DC: AOAC.

Centeno, A. \& Campo, M.G. (2011). Response of mature olive trees with adequate leaf nutrient status to additional nitrogen, phosphorus and potassium fertilization. Acta Hort 888, 277-280.

Ertürk, Ü., Mert, C. \& Soylu, A. (2006). Chemical composition of fruits of some important chestnut cultivars. Brazilian Archives of Biology and Technology Vol.49, n.2:pp. 183-188.

Fageria, N.K., Baligar, V.C. \& Jones, C.A. (2011). Growth and Mineral Nutrition of Field Crops. 3rd Edition, CRC Pres, Boca Raton, FL, USA.

FAO. (2019). World chestnut production list. Website http://www.fao.org/faostat/en/\#data/QC Visited on date: $03 / 06 / 2020$

Güneş, A., Inal, A., Bagcı, E.G. \& Kadığlu, Y.K. (2010). Combined effect of arsenic and phosphorus on mineral element concentrations of sunflower. Communications in Soil Science and Plant Analysis, 41, 361-372.

Imas, P. (1999). Quality aspects of K nutrition in horticultural crops. Workshop on Recent Trends in Nutrition Management in Horticultural Crops. Dapoli, Maharashtara, India.

Kacar, B. \& Katkat, V. (2011). Bitki Besleme. Nobel Akademik Eğitim Danışmanlık, Yayın No: 1219. ISNB: 978-605-320-121-2. 678 s. 6. Basim. Ankara.

Kumar, A.R., Kumar, N. \& Kavino, M. (2006). Role of potassium in fruit crops - A review. Agric.Rev.,27(4), 284-291. 
Mengel, K. (1991). Ernährungund Stoffwechsel der Pflanze. G.F.V. Jena.

Rodrigues, M.A., Pereira, A., Cabanas, J. E., Dias, I., Pires, J. \& Arrobas, M. (2006). Crops useefficiency of nitrogen from manures permitted in organic farming. Eur. J. Agron 25, 328335.

Ross, F.A. (1959). Dinitrophenol Methods for Reducing Sugars. Potato Processing, In: Talburt, W.F. And Smith, O. (Eds.). A VI Publishing Comp. Connecticut. pp. 469-470.

Rutter, P.A., Miller, G. \& Payne, J.A. (1990). Genetic resources of temperate fruit and nut crops. Acta Horticulturae, No: 290, Vol: II, Chapter: 16, 761-788.

Yağmur, B., Okur, B., Tuncay, Ö. \& Eşiyok, D. (2019). Farklı Ekim Zamanı ve Azotlu Gübre Uygulamalarının Tere (Lepidium sativum L.) Bitkisinin Azot Fraksiyonları ve Bitki Besin Maddesi İçeriğine Etkileri. Yüzüncü Yıl Üniversitesi Tarım Bilimleri Dergisi, 29 (3) , 388- 396.

Vosconcelos, M.C.M.B., Bennet, R.N, Rosa, E.A.S., \& Ferreira- Cardoso, J.V. (2010). Composition of European chesnut (Castanea sativa Mill.) and association with health effects: fresh and processed products. J. Sci. Food Agr. 90. p: 1578-1589

Wahl, T. (2002). The Iowa Chestnut Grower's Primer. Published 2002, Revised 2017 2nd Edition. $\mathrm{P}: 10-11$. 